\title{
Dullness Versus Vivacity: A Study of Gustave Flaubert's Madame Bovary
}

\author{
Himani Sharma \\ Assistant Professor \\ Department of English \\ Patel Memorial National College \\ Rajpura, India \\ himanisharma45@gmail.com
}

\begin{abstract}
An ideal marriage is a state of being equal in every way which is built on a healthy dose of admiration, on understanding, dedication, trust and loyalty. French novelist Gustave Flaubert has raised the same issue in his most discussed work Madame Bovary. Flaubert was most notable for being the leading exponent of literary realism in French literature. There were writers before Flaubert who tried their hands at realism but not all of them, as was the case in the work of Flaubert. The fiction Madame Bovary is a dedication to its heroine's sentiments. Though she has been tagged, adulterous, a failed wife and failed mother, we feel pity for her. She really demands our sympathy since she was unable to achieve that eternal pleasure throughout her whole life. Her mere guilt was her sensible nature which shattered all her dreams. The present paper is an attempt to study her innocence by analysing her nature, sentiments and imagination in depth.
\end{abstract}

Keywords: Guilt, Adultery, Dullness, Marriage, Ambitions, Dreams, Lover. 
Gustave Flaubert was one of the most important writers of $19^{\text {th }}$ century and with him French novels were highly appreciated. Henry James called him ' novelists' novelist. His literary influence has been stated by Nabokov, whereby he talked about his supremacy over Marcel Proust, James Joyce and Anton Chekov. Flaubert has made literature a pure art. He was highly concerned about political, social and religious matters of society. He was possessing the special concern for bourgeois. He was possessing pessimistic attitude towards life which created masterpieces and he will always be eulogised for his genius. Apart from the revolutionary and most influential work Madame Bovary, he wrote 'Salammbo', 'Sentimental Education', 'The Temptation of Saint Anthony' and Three Tales. In the present work, Flaubert's own view of life is visible,

“ The work has revealed Flaubert's narcissism, his onanism, his idealism, his solitude, his feminity, his passivity"( Sartre: 1964)

Madame Bovary was published in 1857. The novel has been considered ultimate for its depiction of realism and impressionism. The book is all about its tragic heroine named Emma. Though she did infidelity and became adulterous, yet she can be called innocent. She was a girl of passions and ambitions, lover of wealth and beauty, fond of reading romantic and imaginary novels. Flaubert's uniqueness can be seen in her portrayal, she was undoubtedly a heroine of some romantic novel. Not only her appearance but her thoughts, ambitions and sentiments were quite the same as of those heroines. Being an innocent maiden, she never understand the true meanings and responsibilities of marriage. In the hopes of changing her life style, her atmosphere, her friends and relatives, she got married, thinking she would get her princecharming since she herself is heroine. In no time, she got disillusioned and disappointed with her wedding, she has had the realization that it has different meanings in fantasy and in reality. 
Getting disappointed she was unable to find those pleasures and joys about which she has read in books. Charles was not more than an ordinary man, a dull character with whom Emma's vivacity was a mismatch. He remained stupid towards the end, incapable to understand Emma. He had no desires, ambitions and dreams at all. Emma became hopeless, "The adulterous passion, felt as liberation, awakening, spontaneous growth, authentication of the self, is the natural correlative. But the need to have an unforced but responsible relationship to love and to be loved- either in marriage or out of it,brings into play the dangerous impulses of the self...” ( Poulet: 1964)

Flaubert has analysed Emma's character masterly and showed her high sentimenatalist and romantic. Being a lover of romantic fictions and and music, she had read secret encounters with lovers, midnight marriage with torches, ideas of eloping with great interest. She had special concern for historical and gothic fiction. Since she was in the habit of living in the dream world, she could be called escapist. She loved fantasy more than reality. On the other hand Charles was a simple man, who had always been manipulated by female world, first by his mother, then by his middle-aged wife. He was a good husband but can't be called an ideal one since he was never concerned for Emma's ambitions and emotions. He made efforts to make her happy but his all efforts were just limited to money. He never thought that money is not enough for wife's contentment. Looking at this way, whole guilt can't be placed on Emma but on Charles too who never paid attention to her romantic and sexual needs and desires. Emma was in search of a hero of her romantic fictions but Charles was not possessing any quality of a hero.

"Emma appears as the eternal feminine in her tragic relationship throughout her life with the male, presented by Flaubert in many forms, culminating in the very poison itself, the etymological sense of the word arsenic being 'male'. ( Lowe:1984) 
Emma was convent-educated and was interested in love songs about love, lovers, horse riding, sombre forests, sobs, tears, kisses, nightingales in shady groves, gentleman brave as lions, gentle as lambs, gentleman with well-dressed attitude. She had great interest in Walter Scott and was well read his historical and gothic fictions. She had a cult for all beautiful and unhappy women Joan of Arc, Heloise, Agnes, Sorel and she had sympathy for their poor destiny. She was adventurous, delicate and intelligent hence had a great impression on every male whether it was Heloise, Leon, Lheureux or Rodolphe. She had interest in visiting grand balls, sophisticated cities like Paris. She was superior to Charles in every way. Every time, she was feeling herself a caged bird in the name of conventional marriage.

“Emma's tragedy is that she is not free. She sees her slavery as not only product of her social class- the pithy bourgeoisie as immediatized by certain modes of life and prejudices- and of her provincial milieu- a tiny world where the possibilities of accomplishing anything of note are few- but also and perhaps most importantly a consequence of her being a woman”. ( Liosa: 1986)

It can be never stated that Emma never knew the true meaning of marriage. She had married in the hope of turning all her dreams into reality. Though marriage occurred with her consent and her father's consent but she began considering her wedding a misfortune which shattered all her dreams in a moment and declared her an ordinary housewife, not any heroine. Having blamed Charles for all her misfortunes, she determined to fulfil all her desires with Rodolphe and Leon later. Though she was adulterous but her desires were so strong that these can't be suppressed and hence compelled her to do so. She has accepted that she had been deceived in the name of marriage.

" Before marriage, she thought herself in love; but the happiness that should have 
followed this love not having come, she must, she thought, have been mistaken. And Emma tried to find out what one meant exactly in life, by the words, felicity, passion, rapture, that had seemed to her so beautiful in books... The comparisons of betrothed, husband, celestial lover and eternal marriage that recur in sermons, stirred within her soul depths of unexpected sweetness" ( Flaubert: 2003)

Leon Dupuis. a young man with high ambitions to study law was attractive, idealistic and romantic, seemed an oar to Emma when the boat of her life was about to sink. Leon was possessing every quality which she was looking for in her male partner. He was sensible, book lover and good looking. His mannerism, talks and ambitious nature had a great impression on Emma. The ideas of deceiving never had in her mind since Leon was the last hope who could save her life. She was full of gloomy melancholy before his arrival. Leon's decision of leaving Yonville made her physical and mental health worse. Emma's mere guilt was not to accept her fate in the name of Charles as husband,

"What happy afternoons they had seen alone in the shade at the end of the garden! He read aloud, bareheaded, sitting on a stool of dry sticks, the fresh wind of the meadow set trembling the leaves of the book and the nasturtiums of the arbour. Ah! he was gone, the only charm of her life, the only possible hope of joy. Why had she not seized this happiness when it came to her? Why not have kept hold of it with both hands, with both knees, when it was about to flee from her? And she cursed herself for not having loved Leon”. ( Flaubert: 2003)

She became aware of Charles's dullness just after the marriage and realized his passivity. She always thought him 'a poor creature', not an ideal man whom she was looking for. His failed attempt of club-foot operation was a blow upon Emma and this was the reason why she had a 
desire of baby boy since she wanted a complete man instead she gave birth to Berthe. Charles's dullness was irritating her every moment,

"Everything in him irritated her now, his face, his dress, what he did not say; his whole person, his existence in fine. She repented of her past virtue as of a crime..." ( Flaubert: 2003)

Rololphe Boulanger, a wealthy landlord was very familiar with the art of seducing women since he studied the psychology of women. He had no love for Emma, his sole purpose was to seduce her. With the art of courtship and flattery, he became successful in trapping her. Boulanger rode a strong horses in a velvet jacket, full of silken laces and Emma, poor soul, considered him the real hero of her life. Emma was suffering a lot in the company of Charles. So when Rodolphe entered into her life, her hopes were high. Her words are the expression of her madness

" But I have been patient; I have suffered for four years. A love like ours ought to show itself in the face of heaven. They torture me! I can bear it no longer! Save me". ( Flaubert: 2003)

Her sanity became questionable, when she was served notices from Lheureux demanding payment from whom she borrowed higher amount of money. She made her way towards selfdestruction since all refused to help her. Left with no option before, she was compelled to commit suicide. Flaubert intimates that Emma's this attempt resulted from Charles's dullness, Leon's refusal and Rodolphe's betrayal, hence faced violent death. Though Emma deceived Charles, mocked her marriage, lost her chastity but her suppressed ambitions, her vivacious, adventurous and romantic view of life can't be neglected. She failed to be a sensible wife and devoted mother but it was so as Charles was not an ideal husband. Though she was guilty but the 
whole blame can't be placed on her. She was in need of escape, if death were an escape from the meshes of her life, she escaped. Towards the end, she achieved nothing meaningful from her life, but betrayal. 


\section{Works Cited}

Sartre, Jean- Paul. "Flaubert”. “Flaubert: A collection of Critical Essays”. USA: Prentice $\mathrm{p}, 1964$.

Poulet, George S.“ Flaubert”. “Flaubert: A collection of Critical Essays”.USA: Prentice $\mathrm{p}, 1964$.

Lowe, Margaret. “ Towards the Real Flaubert- A Study of Madame Bovary”. London; Claredon P, 1984.

liosa, Mario Vargas. "The Perpetual Orgy: Flaubert and Madame Bovary”. Translated. Helen Lane, New York, Farrar, Straus, Giroux, 1986.

Flaubert, Gustave. "Madame Bovary”, Kalyani Publishers, 2003. pp. 27-28

Ibid,pp. 94.

Ibid,pp. 141.

Ibid...pp.148. 